\title{
In Vitro Evaluation of Hen Eggshells Addition in Rice Husk on Litter Properties
}

\author{
Rudi Afnan*, Danar Bias Idana, and Ahmad Yani \\ Faculty of Animal Science, Bogor Agricultural University IPB \\ Jl. Agatis Kampus IPB Darmaga, Babakan, Dramaga, Bogor, West Java 16680 \\ *Corresponding author's email: rudiafnan@yahoo.com
}

\begin{abstract}
Eggshell as a by-product of hennery (hen stable) and hatchery is mainly constructed from CaCO3. This research aimed to evaluate the addition of hen eggshell powder at different concentration in litter on water content, $\mathrm{pH}$, microorganism, and $\mathrm{NH} 3$ concentration of litter. Rice husk as litter material, hen eggshell powder at a concentration of $0 \%, 5 \%, 10 \%$, and $15 \%$ and hen manure were thoroughly mixed. After 24 hours, the concentration of water content, $\mathrm{pH}$, microorganisms amount and $\mathrm{NH} 3$ in each treatment were measured. This research was completely randomized designed with 3 repetitions. Results showed the progressive addition of hen eggshell powder in litter until $15 \%$ increased $\mathrm{pH}$ and decreased water content, number of microorganisms and $\mathrm{NH} 3$ concentration. The addition of $15 \%$ hen eggshell powder in litter revealed best litter properties.

Keywords: ammonium, hen eggshell, litter, $\mathrm{pH}$, water content
\end{abstract}

Abstrak. Kerabang telur merupakan hasil ikutan dari peternakan ayam petelur dan industri penetasan dan memiliki komposisi utama kalsium karbonat $\left(\mathrm{CaCO}_{3}\right)$. Penelitian ini mengevaluasi penambahan tepung kerabang telur pada berbagai konsentrasi terhadap konsentrasi $\mathrm{NH}_{3}$ di litter. Sekam padi sebagai bahan litter ditambahkan tepung kerabang telur dengan 4 konsentrasi berbeda yaitu, $0 \%, 5 \%, 10 \%$, dan $15 \%$ dari berat litter kemudian ditambahkan manur (eksreta) ayam petelur dan diaduk rata. Setelah 24 jam, setiap perlakuan diukur konsentrasi $\mathrm{NH}_{3}, \mathrm{pH}$, kadar air, total mikroba, dan kandungan protein litter. Percobaan menggunakan rancangan acak lengkap yang diulang sebanyak 3 kali. Hasil penelitian menunjukan penambahan tepung kerabang telur hingga $15 \%$ dapat meningkatkan $\mathrm{pH}$ dan menurunkan kadar air, total mikroba, serta konsentrasi gas $\mathrm{NH}_{3}$. Penambahan tepung kerabang telur pada taraf $15 \%$ menunjukkan hasil terbaik.

Kata kunci: gas amonia, kandungan air, kerabang telur, litter, $\mathrm{pH}$

\section{Introduction}

Hazardous gases in the hennery such as ammonium (NH3) which is released from uric acid of chicken manure are the main factor in decreasing laying rate of hen, resulting in offodor and bring negative impact on the human environment. Laying hen production is well performed in comfort environmental condition. The higher the level the gasses, the lower the laying hen production. Good management practices are required to depress ammonium concentration in litter.

Serious problems related to harmful gases occurs in hennery is the presence of ammonium (NH3). Several research findings showed that application of $\mathrm{CaCO} 3$ (calcium carbonate) can decrease ammonium concentration in a litter. Ammonium produced from hen manure has a strong smell and causes problems for hen's health and productivity. Health problems often occur in hen due to ammonium is respiratory tract disorders, reducing oxygen intake, inhibiting body skeleton growth, and increasing mortality (Setyawati, 2004). Ammonium also affects humans to have watery eyes, sneezing, sore throat, chronic cough, shortness of breath, headache, and nausea (Golbabei and Islami, 2000).

Litter serves as feces and urine absorbent to prevent the stable from getting wet or damp. Good litter must be able to absorb water, not dusty, dry, non-toxic, inexpensive, soft, has a good density, abundant, and easily transported. Therefore, rice husk or sawdust, gravel, sand, and lime are usually used. Ammonium content in hennery can be influenced by various factors such as litter management, water content, $\mathrm{pH}$, microorganism amount, and manure protein 
content. Poor litter management can cause hen's manure loading which could increase the ammonium concentration in hennery. Microorganisms role actively in breaking down manure protein content into amino acids which then go through the deamination process to produce ammonium (Svenson, 1990). Optimal water content and $\mathrm{pH}$ for microorganism growth are important factors in ammonium formation (Blake and Hess, 2001).

Lime (calcium oxide) which is composed primarily of calcium carbonate ( $\mathrm{CaCO} 3$ ) serves to reduce ammonium in the air and odor. Lime has been often used in the litter to reduce manure's odor (Murhalien et al., 2011). Eggshell has high calcium content in the form of calcium carbonate around $11 \%$ of the whole egg weight (Yuwanta, 2010). Therefore, it has the potency to use as substitute material of high calcium-containing materials such as lime. Eggshell has good property as calcium material, easy to grind into powder, easy to obtain, available in large quantities, and cheap.

Lots of eggshells are commonly treated as waste. They are accumulated and unutilized that can lead to environmental pollution. Central Bureau of Statistics released data in 2015 that egg production in Indonesia amounted to 1.372.829 tons which made 151.011 tons eggshell yearly.

This research aims to evaluate the addition of eggshell in rice husk as hen litter material on litter properties. On the other hand, this research may contribute to reducing waste and save the environment.

\section{Materials and Methods}

Eggshells were collected and cleaned. Both inside and outside membranes were removed and washed with water. Clean eggshells were then sun dried for a day and followed by oven drying at $105^{\circ} \mathrm{C}$ for 2 hours. Dried eggshells were milled 2 times by a milling machine to get a smooth powder. The eggshell powder was then activated by heating in a furnace at $900^{\circ} \mathrm{C}$ for 2 hours and allowed to stand for 24 hours (Jasinda et al., 2013).

Manures from 42-week-old hen were collected and stored for 3 days in plastic tubes. A total of 12 jars was provided and each was filled with $400 \mathrm{~g}$ of rice husk. Eggshell powder was added in jars with different concentration $(0 \%$, $5 \%, 10 \%$, and $15 \%)$. Each concentration level had 3 repetitions. An amount of $150 \mathrm{~g}$ hen manure was put into each jar and then stirred thoroughly. Every jar was tightly closed and connected with pipe to Erlenmeyer tube for 24 hours' incubation, afterward.

Water content, $\mathrm{pH}$, microorganism amount, $\mathrm{NH} 3$ concentration, and protein content was measured for every treatment. Water content was measured by heating $10 \mathrm{~g}$ samples at $105^{\circ} \mathrm{C}$ for 2 hours and then weighed. $\mathrm{pH}$ was measured by dissolving $5 \mathrm{~g}$ of sample in distilled water and then measured by $\mathrm{pH}$ meter. The number of microorganisms was counted by using a total plate count (TPC) method. Ammonium concentration was measured by the Nessler method.

This research was completely randomized designed. All treatment was 3 times repeated. Data were subjected to analysis of variance and Duncan's multiple range test (Mattjik and Sumertajaya, 2006).

\section{Results and Discussion}

The crude protein content of experimental litter was $14.30 \%$ and $11.16 \%$ to $11.64 \%$ for treated and not treated, respectively. Addition of eggshells lowered the litter crude protein content but statistically not significant. Fontenot (1999) reported that the crude protein content of pure hen manure was $28 \%$ on average. The experiment litter was a mixture of manure and rice husk. Eggshells have low protein content (Rahmawati and Nisa, 2015) but majority particles are carbonate and calcium elements (Tsai et al. 2006). Meanwhile, rice husk has only 2.4\% crude protein (Praes et al., 2014). 
Therefore, the crude protein content of mix litter was lower than Fontenot finding.

The addition of eggshell powder lowered significantly $(P<0.05)$ the litter water content. The higher the concentration levels, the lower the water content. The reduction of water content caused by the capability of lime $(\mathrm{CaO})$ as the main component of eggshell powder to absorb water. Calcium oxide of eggshell powder absorbs water and reacts to form calcium hydroxide (Kusnoputranto and Jaya, 1984). Increasing eggshell powder means increasing absorb capacity and results in diminishing water content of litter. On the other hand, the eggshells powder also has good pores volume as water adsorption material (Tsai et al., 2006).

Condition of $\mathrm{pH}$ litter is influenced by the environment, manure conditions, and water content. Fresh hen manure has an alkaline $\mathrm{pH}$ ranging from 8-9 (Weaver, 2001). The result showed that litter without eggshell powder addition had normal pH. Meanwhile, litter with eggshell powder addition showed more alkaline.

A high content of hydroxide ions $\left(\mathrm{OH}^{-}\right)$makes element becomes more alkaline (Chang 2008). Alkali elements addition such as lime can raise $\mathrm{pH}$ litter (Shah et al., 2006). Calcination by thermal treatment in making the eggshell powder more alkaline. Lime content of eggshell powder in litter reacts with water and produces $\mathrm{Ca}(\mathrm{OH})_{2}$ which is alkaline. The increasing reaction of calcium with water producing more $\mathrm{OH}^{-}$ion and in turn increase $\mathrm{pH}$ (Hakim, 1986).

Other results showed microorganism amount was significantly reduced by the increase of eggshells powder addition. Microorganisms activity decrease in toxic condition. Calcium hydroxide $\left(\mathrm{Ca}(\mathrm{OH})_{2}\right)$ belongs to disinfectant compounds that can reduce bacteria. Calcium hydroxide through its $\mathrm{OH}^{-}$ion acts as antimicrobial and inactivates microorganism cytoplasmic membrane enzymes and change chemical component and nutrients that cause toxic to microorganism. Inactivation of enzymes in the cytoplasmic membrane will influence the process of growth, cell division, and bacterial metabolic activity (Signoretto et al., 2000). This calcium hydroxide in the litter is derived from lime oxide $(\mathrm{CaO})$ in eggshell powder mixed with water. Therefore, the number of microorganisms was reduced (Madigan et al., 2009).

Reductions of bacteria number also influenced by eggshell powder ability in absorbing water. Water is an important component to grow and develop bacteria. Water is the largest part of protoplasm that has role plays in any bacterial reaction. Low water content causes the bacterial activity to decrease. Bacteria can also develop at an optimal pH of 8 to 9 (Blake and Hess 2001). The addition of eggshell powder showed the $\mathrm{pH}$ produced more alkaline than optimal $\mathrm{pH}$ bacterial growth.

Ammonium production in the litter was also significantly reduced. Koerkamp (1996) mentioned about $20 \%$ of the nitrogen in manure will be degraded to ammonia within 12 hours with concentrations about $6.61 \mathrm{ppm}$. Ammonium concentration is influenced by feed, humidity, $\mathrm{pH}$, nitrogen content of litter or manure, and microorganisms (Rohaeni, 2005).

Table 1 Properties of experimental litter after addition with different eggshell powder concentrations

\begin{tabular}{lcccc}
\hline \multicolumn{1}{c}{ Traits } & \multicolumn{4}{c}{ The concentration of eggshells powder (\%) } \\
\hline Protein content (\%) & 0 & 5 & 10 & 15 \\
Water content (\%) & $14.30 \pm 1.90$ & $11.53 \pm 1.72$ & $11.16 \pm 2.00$ & $11.64 \pm 1.31$ \\
$\mathrm{pH}$ & $72.67 \pm 1.53^{\mathrm{a}}$ & $68.01 \pm 2.65^{\mathrm{a}}$ & $60.02 \pm 3.06^{\mathrm{b}}$ & $57.67 \pm 3.06^{\mathrm{b}}$ \\
Microorganisms (10 $\mathrm{cfu} / \mathrm{ml})$ & $63.30 \pm 8.60^{\mathrm{a}}$ & $57.20 \pm 8.91^{\mathrm{a}}$ & $8.93 \pm 0.64^{\mathrm{b}}$ & $6.55 \pm 1.26^{\mathrm{b}}$ \\
$\mathrm{NH}_{3}$ concentration $(\mathrm{ppm})$ & $2.87 \pm 0.45^{\mathrm{a}}$ & $2.67 \pm 0.49^{\mathrm{ab}}$ & $1.63 \pm 0.25^{\mathrm{b}}$ & $0.66 \pm 0.25^{\mathrm{b}}$ \\
\hline
\end{tabular}

Mean values within a row with different superscripts differ significantly $(P \leq 0.05)$ 
Ammonium is produced from the decomposition of manure protein through proteolysis by microorganism proteases to form amino acids then undergoing deamination (Svenson 1990). Urea and uric acid in manure are hydrolyzed to ammonium carbonate by urease enzymes secreted by bacteria. Ammonium carbonate is easily broken down into ammonium, carbon dioxide, and water. The process of releasing ammonium according to Humaidi et al. (2006) begins from the overhaul of carbohydrates in manure into $\mathrm{H}_{2} \mathrm{O}$ and $\mathrm{CO}_{2}$. Both molecules will react to form $\mathrm{H}_{2} \mathrm{CO}_{3}$ which can be ionized into $\mathrm{HCO}_{3}^{-}$and $\mathrm{CO}_{3}$. Meanwhile, deamination proteins are trapped in water to form ammonium ion $\left(\mathrm{NH}_{4}{ }^{+}\right)$. Existence of $\mathrm{HCO}_{3}{ }^{-}$ encourage $\mathrm{NH}_{4}{ }^{+}$to release protons to $\mathrm{HCO}_{3}{ }^{-}$and then releasing ammonium.

The eggshells powder can decrease ammonium concentration through the reaction of calcium ions $\left(\mathrm{Ca}^{2+}\right)$ with $\mathrm{HCO}_{3}^{-}$thereby maintaining $\mathrm{NH}_{4}{ }^{+}$. Therefore, the ammonium concentration is reduced (Humaidi et al., 2006). The reduction of ammonium concentration influenced by eggshells powder ability to decrease bacterial activity. The increase of ammonium and bacteria activity was capable of breakdown amino acids into ammonium (Estevez, 2002). The low water content and the alkaline $\mathrm{pH}$ of the litter become a constraint for bacteria to grow and to breakdown amino acids.

\section{Conclusions}

The eggshells powder addition in rice husk was effective in reducing water content, increasing $\mathrm{pH}$, reducing water content, reducing the number of microorganisms and reducing ammonium concentration in the litter. The addition of $15 \%$ eggshells powder in the litter was revealed to be the best result in reducing water content, $\mathrm{pH}$, microorganisms number and ammonia concentration in litter.

\section{References}

Blake JP and JB Hess. 2001. Litter Treatments for Poultry. Circular ANR-1199. Alabama Cooperative Extension System, Auburn University. Alabama.

Chang R. 2008. Kimia Dasar: Konsep Konsep Inti. Jilid 2., Erlangga, Jakarta. 327 pages.

Estevez I. 2002. NH3 and Poultry Welfare. Poultry Perspectives. Vol 4(1):1-3.

Fontenot JP. 1999. Nutrient Recycling: The North American Experience. Asian-Aus J Anim Sci. Vol 12(4):642-650.

Golbabei F and F Islami. 2000. Evaluation of Worker's Exposure to Dust, Ammonia and Endotoxin in Poultry Industries at Province of Isfahan, Iran. Industrial Health. Vol 9(38):41-46.

Hakim N. 1986. Dasar-Dasar IImu Tanah. Universitas Lampung, Lampung. 448 pages

Humaidi MF, Charlena dan IH Suparto. 2006. Effect of Lime Addition on $\mathrm{NH}_{3}$ Releasing of Hen Manure. Thesis. Institut Pertanian Bogor, Bogor (ID). (in Indonesian with abstract in English)

Jasinda, Iriany dan Krisnawati. 2013. Penjerapan Logam Kadmium $\left(\mathrm{Cd}^{2+}\right)$ dengan Adsorben Cangkang Telur Bebek yang telah Diaktivasi. J Teknik Kima USU. 2(3):28-32.

Koerkamp GPWG. 1996. Ammonia Emissions from Aviary Housing System for Laying Hens Inventory, Characteristics and Solution. Thesis. IMAG-DLO, Wageningen.

Kusnoputranto H dan Jaya IM. 1984. Khasiat Pembubuhan Kapur Tohor dalam Hal Daya Membunuh Mikroorganisme (E. Coli) dan Peningkatan Alkalinitas pada Lumpur Tinja dari Septic Tank Jamban Jamak di DKI Jakarta. Jakarta: Fakultas Kesehatan Masyarakat, Universitas Indonesia, Jakarta.

Madigan MT, JM Martinko, PV Dunlap and DP Clark. 2009. Brock Biology of Microorganism $12^{\text {th }}$ Edition. Pearson Benjamin-Cummings, San Fransisco.

Mattjik AA and IM Sumertajaya. 2013. Perancangan Percobaan dengan Aplikasi SAS dan Minitab. PT Penerbit IPB Press, Bogor. 350 pages

Murhalien, Achmanu dan R Rachmawati. 2011. Meningkatkan Produksi Ayam Pedaging Melalui Pengaturan Proporsi Sekam, Pasir, dan Kapur Sebagai Litter. J Teknik Tropika. Vol 12(1):38-45.

Praes MFFM, OM Junqueira, AA Pereira, RS Filardi, KF Duarte, S Sgavioli, JCR Alva and CHF

Rahmawati WA and FC Nisa. 2015. Fortifikasi Kalsium Cangkang Telur pada Pembuatan Cookies (Kajian Konsentrasi Tepung Cangkang Telur dan Baking Powder). J Pangan \& Agroindustri. 3(3):1050-1061.

Rohaeni ES. 2005. Dampak Pencemaran Lingkungan dan Upaya Mengatasinya. Poultry Indonesia. Maret 2005: 58-61. 
Rudi Afnan, et al/Animal Production. 20(2):119-123, 2018

Accredited by Kemenristek Dikti No 32a/E/KPT/2017. ISSN 1411-2027

Setyawati SJA. 2004. Effect of Various Litter Material in Broiler Maintenance on Performance, Blood Profile and Litter Condition. Thesis. Universitas Diponegoro, Semarang. (in Indonesian with abstract in English)

Shah S, P Westerman and J Parsons. 2006. Poultry Litter Amendments. North Carolina Co Extension Service, Carolina.

Signoretto C, MDM Lleo, MC Tafi and P Canepari. 2000. Cell Wall Chemical Composition of Enterococcus Faecalis in the Viable but
Nonculturable State. Appl Environ Microbiol. Vol 60(5):1953-1959.

Svenson L. 1990. Putting The Lid on The Dung Head. Acid Environ Mag. 9:13-15

Tsai WT, JM Yang, CW Lai, YH Cheng, CC Lin and CW Yeh. 2006. Characterization and Adsorption Properties of Eggshells and Eggshell Membrane. Bioresouce Technology. Vol 97(6): 488-493.

Yuwanta T. 2010. Telur dan Kualitas Telur. UGM Press, Yogyakarta. 